\title{
Heterogeneity of Monetary Policy Spillovers to Monetary Responsiveness in Emerging Market Economies
}

\author{
Jacinta Bernadette Rico Shirakawa
}

\begin{abstract}
Discussions about monetary policy spillovers increased as major advanced economies move to policy normalization. In this paper, $I$ investigate the differences in policy spillovers on monetary policy setting of emerging market economies. In particular, I investigated how interest differentials from major advanced economies, US, ECB and Japan, influence the movements of interest rates in emerging market economies. Using panel fixed effects regression, the results of this study show heterogeneity in the significance of policy spillover from US, ECB and Japan to emerging market economies. The results support previous findings that international monetary policy spillovers influence movements in short term interest rates, which is not explained by policy factors.
\end{abstract}

Index Terms-Monetary policy, recession, business cycle, emerging market economies.

\section{INTRODUCTION}

Emerging market economies (EMEs) have come a long way in developing monetary policy responsiveness to economic downturns. In the past, EMEs could not ease monetary conditions despite undergoing recessions or financial crises [1]. Some examples that come to mind are the lack of monetary policy responses during the Latin American Crisis in the 1980s and the Asian Financial Crisis in the late 1990s. Through reforms, EMEs "graduated" and have been able to conduct countercyclical monetary policy [2].

Despite improvements in monetary policy responsiveness, EMEs still face challenges in maintaining monetary responsiveness. For one, ultra-low interest rates in advanced economies have placed downward pressures on the interest rates of EMEs. Weak global economic conditions, falling commodity prices, near zero or negative interest rates in major economies placed interest rates in EMEs in a downward trajectory. A recent example of the effect of ultra-low interest rates spilling over to neighboring countries is when some EU economies outside the Eurozone adopted negative interest rate policy to defend their currency from sudden capital inflows and speculators as well as to prop up economic growth. In Asia, Singapore is also reaching the zero nominal interest bound. If another severe economic downturn strikes, policymakers in countries with low interest rates may not have enough policy space to conduct countercyclical monetary policy.

Empirical studies on monetary policy spillovers are not scarce. Takáts and Vela show that monetary policy in advanced economies can influence policy rates in EMEs [3].

Manuscript received May 3, 2017; revised October 8, 2017.

Jacinta Bernadette Rico Shirakawa is with Waseda University, Tokyo, Japan (email: jbrico@aoni.waseda.jp).
Recent empirical studies primarily focus on the impact of US monetary policy spillovers to other countries. Belke and Gros provided evidence that the ECB followed the Fed in their interest rate decisions [4]. Fratzcher et al. [5], Chen, et al., [6] and Tillman [7] examine the effect of changes in the US Fed Funds Rate and the US quantitative and qualitative easing to EMEs. Hofmann and Takáts show that US monetary policy affects policy, short-term and long term interest rates in EMEs and small advanced economies [8].

The expected impact of monetary policy spillovers from advanced countries to EMEs can vary based on the depth of the trade and financial ties between advanced economies and the EMEs sensitivity to these factors [9]. In addition, advanced economies can affect aggregate demand in EMEs through the exchange rate. For instance, when setting interest rates, commodity exporters that are vulnerable to terms-of-trade shocks and real exchange rate shocks also consider stabilizing the real exchange rate. Countries with large holdings foreign debt would try to avoid severe depreciation, which could raise the nominal value of their debt. The gravity model of trade has shown that trade relations are stronger when countries are geographically closer to each other. Hence, the extent that policy spillovers affect trade is stronger between neighbors, particularly those with entrenched production networks [10]. Thus, investigating whether and to what extent monetary policy spillovers affect interest rate determination is necessary.

In this paper, I examine the heterogeneity of the impact of monetary policy spillovers in major advanced economies ${ }^{1}$, US, Japan and Eurozone to EMEs monetary policy. The US, EU and Japan are trade and financial centers in the past decades and thus, is regarded as economic centers; meanwhile, EMEs are of interest because of their increasing economic importance as drivers of world economic growth. Since EMEs are connected to major advanced economies in various degrees, I investigate possible differences in the impact of monetary policy spillover to policy responsiveness in EMEs.

The study is structured as follows. In Section II, I provide a background of policy responsiveness from the onset of the global financial crisis to the present. In this study, I use short-term interest rates to represent monetary policy. I show that while policy responsiveness is associated with the rapid recovery, aggressive monetary responses can also limit the extent the policy rate can go down further. In Section III, I

\footnotetext{
${ }^{1}$ This study identifies monetary policy as interest rates in major reserve currency areas, US, Japan, and EU. This follows the study of Aizenman, Chinn and Ito, which examines the effect of policies in center countries to EMEs [9]. While Aizenman, Chinn and Ito defined center countries to be US, Japan, EU and China, I did not include China among center countries in this study of monetary policy spillovers because China has a long history of pegging to the US dollar.
} 
show that the impact of interest rate policy in major advanced countries is heterogeneous across countries by conducting a fixed effects panel regression using the unexplained components of the difference between the actual and the estimated policy response function. The conclusion is given in Section IV.

\section{Monetary Policy Responsiveness During AND AFTER THE GLOBAL FINANCIAL CRISIS}

While emerging economies escaped relatively unscathed during the onset of the global financial crisis, monetary authorities in EMEs remain vigilant to the developments in advanced countries. Many central banks kept relatively low interest rates amidst weak global economic demand while maintaining vigilant to monetary policy tapering in the US.

During the dawn of the global financial crisis, monetary authorities in both advanced and EMEs began to cut interest rates aggressively in 2007. On average, interest rate cuts were deeper in EMEs in Asia as well as European countries not adopting the Euro compared to advanced economies. Table I shows the average decline of interest rates in advanced and EMEs during expansionary monetary cycles ${ }^{2}$ from 2007 onwards. During this period, the average cumulative decrease in interest rate in one monetary expansion cycle in major advanced economies, US, ECB and Japan is 2.04\%; meanwhile that of Emerging Asia and that of EME in EU ranges from $3.12 \%$ and $12.24 \%$, respectively. Not only did policymakers respond aggressively by adopting large interest rate cuts, monetary authorities in advanced economies also kept countercyclical monetary policy stance for a long time as shown in Table $\mathrm{II}^{3}$. It is not surprising to see that major advanced economies have taken a longer time in keeping an expansionary monetary policy stance, relative to EMEs, which recovered relatively quickly during the recession.

TABLE I: MAGNITUDE OF INTEREST RATE DECLINE, 2007M1 TO 2016M5

\begin{tabular}{cccccc}
\hline \hline & mean & $\min$ & $\max$ & $\mathrm{p} 50$ & $\mathrm{~N}$ \\
\hline All & -7.13 & -27.29 & -0.23 & -4.47 & 15 \\
$\begin{array}{c}\text { Major } \\
\text { Advanced } \\
\text { Emerging } \\
\text { Asia }\end{array}$ & -2.04 & -5.19 & -0.46 & -0.46 & 3 \\
$\begin{array}{c}\text { Emerging } \\
\text { Latin }\end{array}$ & -3.12 & -7.75 & -0.03 & -2.72 & 5 \\
America & -0.53 & -1.17 & -0.13 & -0.29 & 3 \\
$\begin{array}{c}\text { Non Euro } \\
\text { Emerging }\end{array}$ & -12.24 & -12.24 & -12.24 & -12.24 & 2 \\
\hline \hline
\end{tabular}

Source: International Financial Statistics, International Monetary Fund, Author's Calculation

\footnotetext{
${ }^{2}$ The expansionary monetary cycle is determined using the Harding and Pagan algorithm [11]. The Harding and Pagan algorithm is often used in analyzing business cycles. In this paper, I apply the algorithm to track the peaks and troughs of the interest rate movement. The period between the peak and the trough, when interest rate is declining, is considered an expansionary monetary phase. Meanwhile, the period between the trough and the peak when the interest rate is increasing is considered a contractionary monetary phase. The Harding and Pagan algorithm employs censoring rules in determining the peaks and troughs of the interest rate that is each phase should be at least 6 months and a complete cycle should be at least 15 months. With this method, short temporary fluctuations in the short-term interest rates are not identified as a change in policy stance. The policy rates and short-term interest rate data (money market rates) are from the International Financial Statistics (2016) of the International Monetary Fund. I used the SBBQ Stata module by Philippe Bracke [12].

${ }^{3}$ The period of monetary expansion is measured as the number of months from the time interest rate declined until it stopped declining which corresponds to the value of the interest rate at its peak to its trough.
}

TABLE II: ST RATES EXPANSION PERIOD 2007M1 TO 2016M5

\begin{tabular}{cccccc}
\hline & mean & $\min$ & $\max$ & $\mathrm{p} 50$ & $\mathrm{~N}$ \\
\hline $\begin{array}{c}\text { All } \\
\text { Major }\end{array}$ & 23.31 & 0 & 44 & 18 & 16 \\
$\begin{array}{c}\text { Advanced } \\
\text { Emerging }\end{array}$ & 49.00 & 47 & 53 & 47 & 3 \\
$\begin{array}{c}\text { Asia } \\
\text { Emerging } \\
\text { Latin }\end{array}$ & 12.00 & 6 & 24 & 7 & 5 \\
$\begin{array}{c}\text { America } \\
\text { Non Euro } \\
\text { Emerging }\end{array}$ & 16.00 & 12 & 19 & 17 & 3 \\
Source: International Financial Statistics, International Monetary Fund, \\
\multicolumn{5}{c}{ Author's Calculation }
\end{tabular}

The unprecedented aggressive countercyclical monetary policy response of EMEs contributed to the resilience of EMEs during the global financial crisis. Historically, EMEs were not able to conduct expansionary monetary policy during economic downturns. This time, however, they decreased interest rates in response to the global turmoil. The movement of short term interest rates and policy rates from 2007 as well as periods of economic downturns ${ }^{4}$ are shown in Fig. 1. In many countries, it can be observed that interest rates were lowered substantially during the economic downturn experienced from the onset of the global financial crisis. The rapid interest rate cuts have mitigated economic downturn in emerging Asia and Latin America and have allowed their economies to bounce back from the crisis [13].

In contrast, the complexity of the financial crisis in the center of the crisis, the US and EU, impedes their economies from going back to pre-crisis growth levels despite deep and long interest rate cuts. As shown in Fig. 2, since 2007, the peak of the policy rate in the United States was at $5.25 \%$ in August 2007. Since the Lehman Shock, the Fed decreased interest rates to $0.125 \%$ by December 2008 and it stayed in that level until November 2015. In addition, the EU, which was also heavily affected by the financial crisis in the United States, began to decrease in interest rates sharply from September 2008. Albeit triggered even before the global financial crisis, interest rates in Japan, one of the economic centers in the world, has also reached the zero bound.

The bounds of using the interest rate as a policy tool opened doors to unconventional monetary policy. Monetary authorities implemented quantitative and qualitative easing to provide liquidity support to financial institutions on top of the ultra-low (and sometimes zero) interest rates. However, the effectiveness of the policies of monetary policymakers to increase overall demand was curtailed for several reasons. Many banks, which were expected to increase lending as a result of the prolonged and aggressive monetary policy easing, chose to park loanable funds in the form of excess

${ }^{4}$ Economic downturns or recessions are identified using the Harding and Pagan algorithm [11]. The Harding and Pagan algorithm tracks the peaks and troughs of output. For this study, I used industrial production index data, and when unavailable, supplemented by manufacturing production index from from the International Financial Statistics (2016) of the International Monetary Fund. The period between the peak and the trough, when output is declining, is considered an economic contraction phase while the period between the trough and the peak when output is increasing is considered a economic expansion phase. The Harding and Pagan algorithm employs censoring rules in determining the peaks and troughs of the interest rate that is each phase should be at least 6 months and a complete cycle should be at least 15 months. With this method, short temporary fluctuations in output are not considered as a recession. I used the SBBQ Stata module by Philippe Bracke [12]. 
reserves to their central banks. Economic uncertainty has made storing excess reserves with the monetary authorities an attractive alternative to actual lending among banks. Thus, monetary authorities need to implement a policy, which would discourage banks from parking their excess reserves at their central banks.
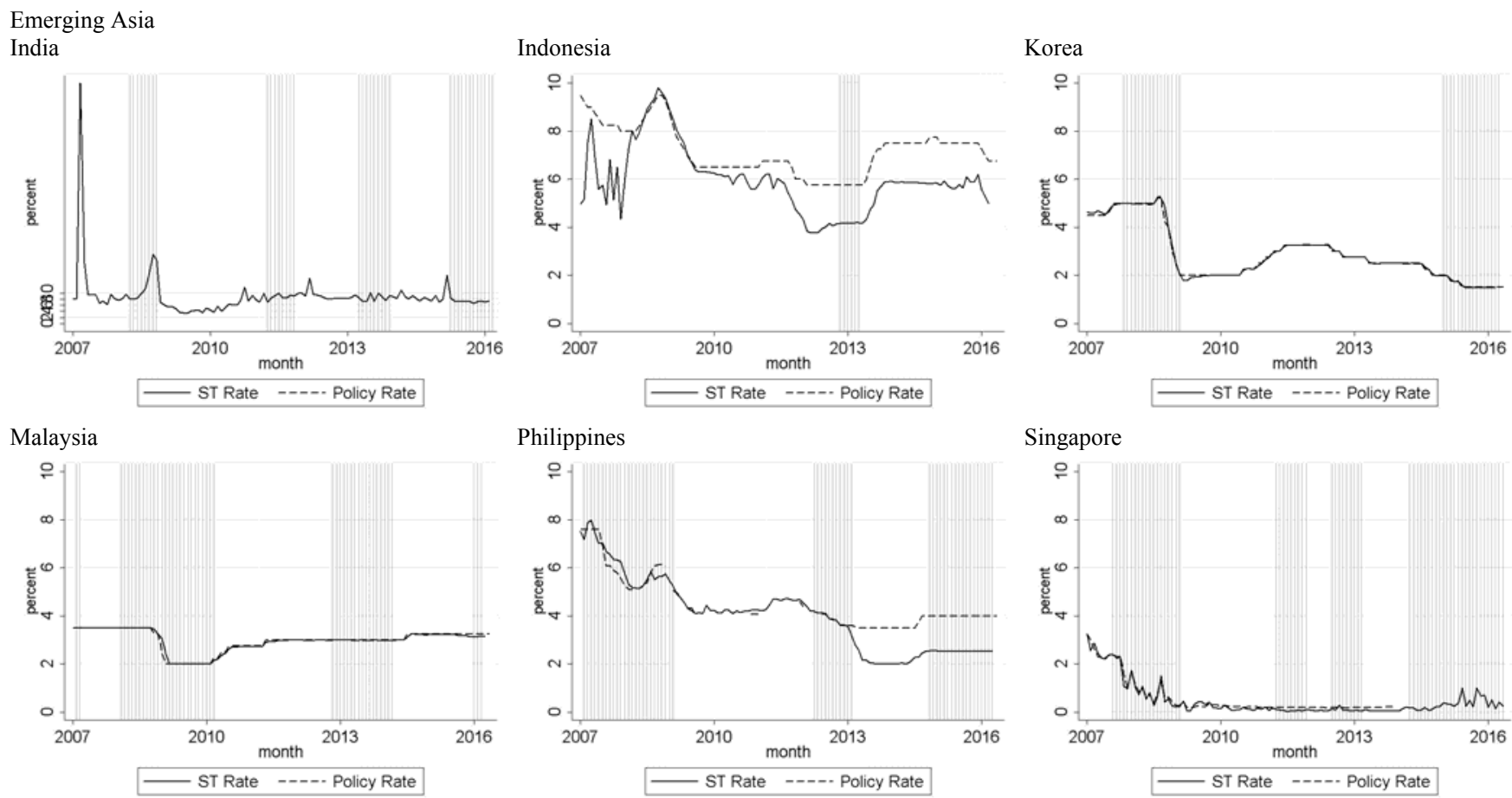

Emerging Latin America
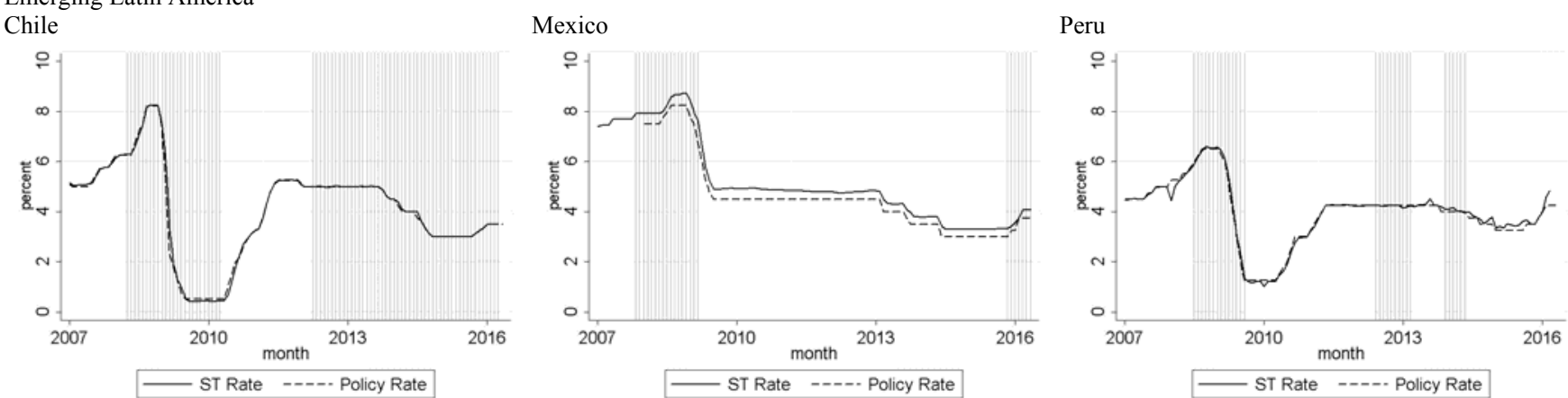

Fig. 1. Short-Term Interest Rate and Policy Rate Emerging Market Economies in Asia and Latin America, (2007-present) Source: International Financial Statistics, International Monetary Fund, Author's Illustration Note: The superimposed gray bars represent economic downturns.

Eventually, policymakers breached the interest rate "zero bound" by adopting negative interest rate policy (NIRP). The intention behind the NIRP is to mobilize bank funds; presently limited to excess bank reserves. By adopting NIRP, monetary policymakers are making it costly for banks to deposit their excess reserves with the monetary authorities with the underlying objective of spurring aggregate demand. Since 2014, central banks in two major reserve currency areas have adopted NIRP. European Central Bank (ECB) and the Bank of Japan (BOJ) reduced nominal interest rates to below zero in June 2014 and January 2016, respectively.

The flattening of interest rates at the near zero or the adoption of negative interest rates can also be observed in other countries which economies are closely tied to the center. EU members are highly integrated in trade and in finance; thus, the Euro crisis affected EU member countries whether or not they adopted the Euro As shown in Fig. 3, these countries have also drastically reduced interest rates since the onset of the financial crisis. In some countries, lowering the interest rate to near zero is not enough and they had to adopt negative interest rates as well. Even before the ECB adopted NIRP, the Danish National Bank (DNB) lowered interest rates below zero in July 2012 to curb speculation. Negative interest rates can discourage volatile capital inflows emanating from interest differentials from major advanced countries with near zero, zero or negative interest rates. Because the Danish Krone is pegged to the Euro, the DNB needed to mitigate speculative capital inflows stemming from the prolonged Euro Crisis. In February 2015, the Swedish Riksbank adopted the negative interest rate policy to fight deflation. Most recently, the Hungarian National Bank (Magyar Nemzeti Bank MNB) also reduced interest rates below zero to contain capital inflow and mitigate currency appreciation.

At present, interest rates in Emerging Asia and Emerging Latin America remain positive and well above the zero, with the exception of Singapore, these economies needs to be vigilant of further monetary policy spillovers from advanced countries. Although low and stable interest rate is in itself considered desirable among policymakers, it can reduce the 
extent in which policymakers can respond to output and inflation fluctuations.

US

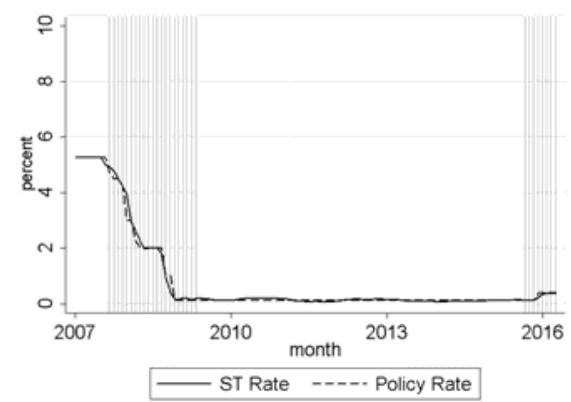

EU

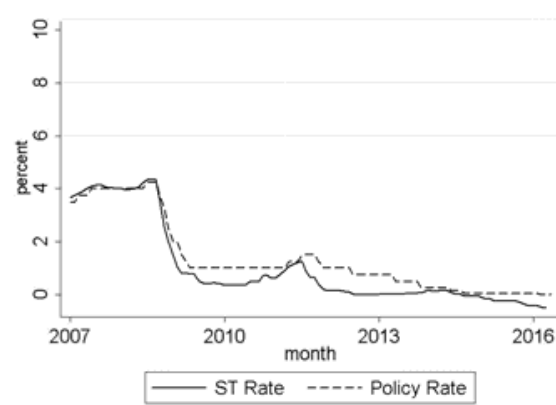

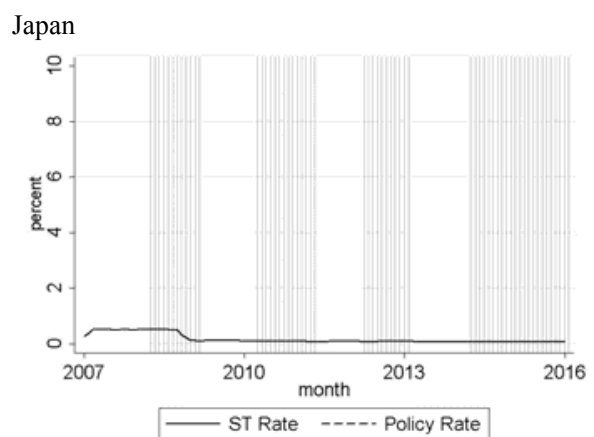

Fig. 2. Short-Term Interest Rate and Policy Rate in US, Eurozone, and Japan (2007-present) Source: International Financial Statistics, International Monetary Fund (2016), Author's Illustration Note: The superimposed gray bars represent economic downturns.
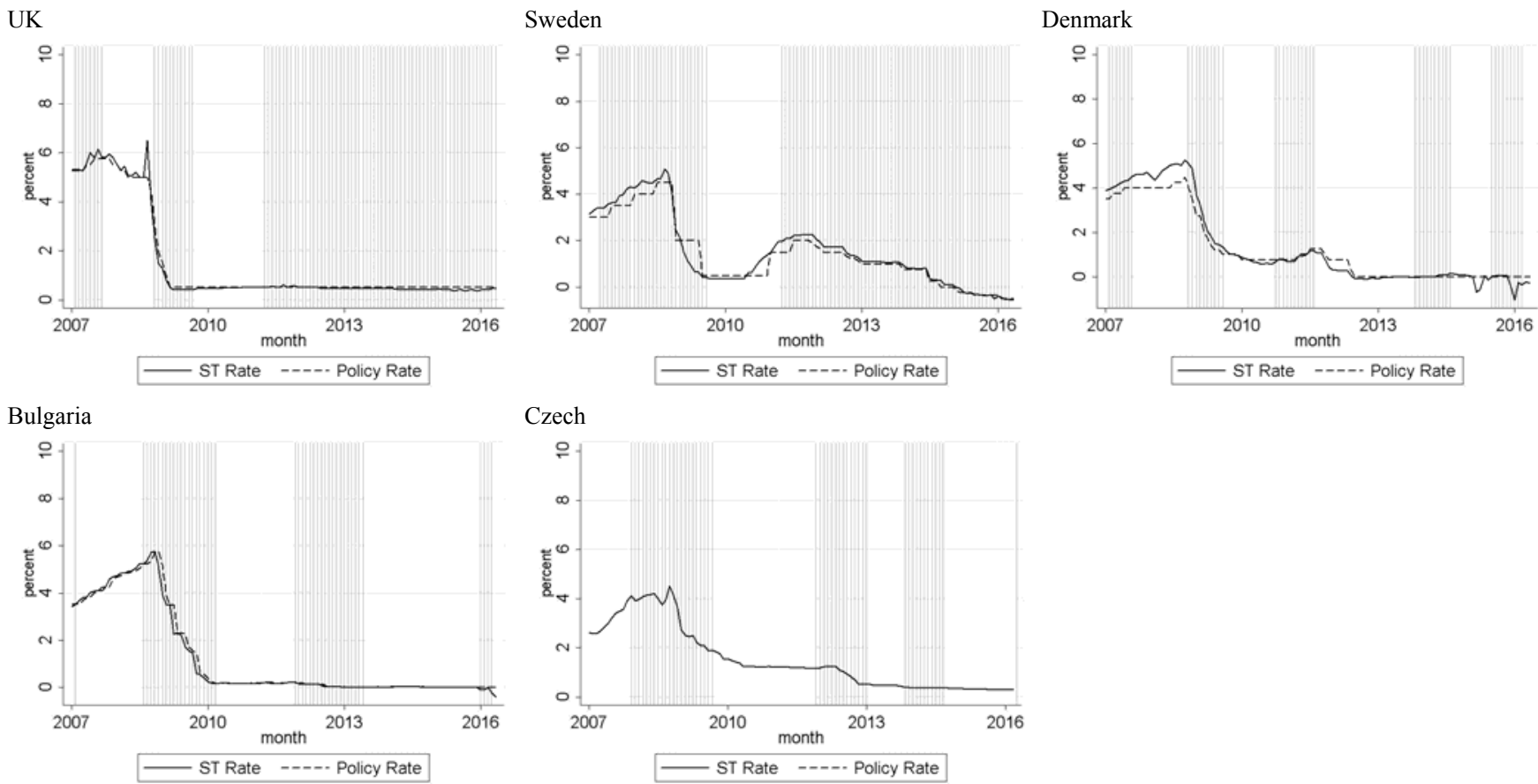

Fig. 3. Short-Term Interest Rate and Policy Rate in EU countries not adopting the Euro reaching zero nominal interest rates (2007-present) Source: International Financial Statistics, International Monetary Fund (2016), Author's Illustration Note: The superimposed gray bars represent economic downturns.

\section{POLICY SPILlOVERS TO EMERGING MARKET ECONOMIES}

I aim to expand the literature on international monetary policy spillovers by investigating whether the effect of policy changes in other major advanced economies, US, Eurozone and Japan is heterogeneous across countries. In particular, I examine whether and how monetary policy spillovers affect EMEs.

In theory, the transmission channel of monetary policy spillovers includes the financial and the trade channels. For instance, ultra-low interest rate policy decreased yields in other instruments incentivizing investors to protect their initial margins or search for arbitrage opportunities by investing in areas with higher interest rates such as EMEs. The sudden inflow of capital could lead to increased exchange rate volatility as well as increased exposure to short term debt denominated in foreign currency. Monetary authorities may deem it wise to decrease policy rates to defend the currency and stabilize large and volatile capital inflows. Similarly, countries with large holdings of international reserves could suffer losses if their currency appreciates substantially. On the other hand, economies with large debt denominated in foreign currency would tend to avoid large currency depreciation to avoid inflating the nominal value of their external debt.

If the driver of monetary policy in advanced countries is the slowdown in aggregate demand, policymakers in emerging economies may also need to loosen monetary policy environment to stimulate or maintain growth. In particular, ultra-low interest rates can signal weak economic growth in advanced economies. In this case, given the long monetary expansion coupled with the commitment of monetary authorities to keep a low interest rate environment in major advanced economies, EMEs have been driven to keep low interest rates as well.

To begin the empirical investigation, first, I identify the main variable of the study. In this study, monetary policy stance is represented by short-term interest rates. Although the use of short-term interest rates in examining monetary 
policy is subject to debate, I deem that short-term rates will suffice for the purpose of this research. Disyatat discusses that short-term interest rates are often an operational target in central banks [14]. He also explains monetary authorities "exercise a close influence" on interest rate in order to give a consistent signal to the market. Kaminsky, Reinhart and Vegh also argue that interest rates can represent the monetary policy stance regardless of the exchange rate regime given imperfect substitution between domestic and foreign assets [1]. Along with the practical reason that interest rate series are available for longer periods of time and for more countries, I employ interest rates to represent monetary policy in this study.

For the same reasons, I use interest rates to represent monetary policy of US, EU, and Japan. In particular, I examine the impact of monetary policy in major advanced economies by taking the interest rate differential of the home country and the center country. While the magnitude of change in interest rate can signal the aggressiveness of monetary policy response, the interest rate differential can signal the extent capital inflows may be directed to the home country, thus affecting the interest rate structure.

Second, in examining the relationship between foreign and domestic interest rates, the policy component of interest rate movements needs to be accounted for. Thus, I employ a model based on the Taylor rule [15] in estimating the reaction function of monetary authorities in EMEs, which incorporates the typical targets of EMEs, output gap and inflation. The equation is given below.

$$
i_{i, t}=\beta_{1}\left(y_{i, t}-y_{i, t}^{*}\right)+\beta_{2}\left(\pi_{i, t}-\pi_{i, t}^{*}\right)+\beta_{4} i_{i, t-1}+\mu_{i, t}
$$

The term on the left is monetary policy represented by the short-term interest rates. The first two terms on the right represent output gap and gap between expected inflation and inflation, respectively. Moreover, the lagged value of the interest rate is added to account for potential interest rate inertia [16]. I use quarterly data from the International Financial Statistics of IMF from 1994 to 2016 covering 48 countries. Details of the calculation method and sources of data are given in the Appendix.

The monetary policy response function is estimated for each country. In order to account for possible changes over the years, I estimated the response function using a moving window of 36 months. The results yield predicted interest rates given its policy components, over time for each country.

From there, we examine the component of the interest rate not explained by policy variables following the finding of Hofmann and Bogdanova that international policy spillovers are one of the sources of persistent deviations from policy rates [17]. I regress the equation below.

$$
\mu_{i, t}=\lambda_{1}\left(i_{i, t}-i_{i, t}^{U S}\right)+\lambda_{2}\left(i_{i, t}-i_{i, t}^{E U}\right)+\lambda_{3}\left(i_{i, t}-i_{i, t}^{J P}\right)+\varepsilon_{i, t}
$$

The dependent variable is the difference between the short-term interest rates and the predicted rates similar to Hofmann and Takáts [8]. Meanwhile, the explanatory variables are the interest rate differentials between a center country and an EME.

\begin{tabular}{|c|c|c|c|c|}
\hline & $(1)$ & $(2)$ & (3) & (4) \\
\hline & All & Emerging Asia & Emerging Latin America & Non-Euro Emerging EU Economies \\
\hline \multirow[t]{2}{*}{ Interest rate differential with US Rate } & $-0.238 * * *$ & $0.181 * *$ & $0.168 * *$ & $-1.900 * * *$ \\
\hline & {$[0.047]$} & {$[0.081]$} & {$[0.070]$} & {$[0.308]$} \\
\hline \multirow[t]{2}{*}{ Interest rate differential with ECB Rate } & $0.494 * * *$ & -0.100 & 0.132 & $2.663 * * *$ \\
\hline & {$[0.063]$} & {$[0.097]$} & {$[0.094]$} & {$[0.391]$} \\
\hline \multirow[t]{2}{*}{ Interest rate differential with Japan Rate } & $-0.248 * * *$ & -0.043 & $-0.206 * * *$ & $-0.831 * * *$ \\
\hline & {$[0.037]$} & {$[0.056]$} & {$[0.059]$} & {$[0.233]$} \\
\hline Constant & [0.109] & {$[0.175]$} & {$[0.161]$} & [1.479] \\
\hline Observations & 9,185 & 881 & 772 & 1,214 \\
\hline Fixed Effects & Yes & Yes & Yes & No \\
\hline Number of cn & 48 & 4 & 4 & 5 \\
\hline
\end{tabular}

TABLE III: REGRESSION RESULTS

Source: Author's Calculations

\begin{tabular}{|c|c|c|c|c|}
\hline & $(1)$ & $(2)$ & (3) & (4) \\
\hline & All & Emerging Asia & Emerging Latin America & Non-Euro Emerging EU Economies \\
\hline \multirow[t]{2}{*}{ Interest rate differential with US Rate } & -0.024 & $0.163^{* *}$ & $0.251 * * *$ & $-0.391 * * *$ \\
\hline & {$[0.023]$} & {$[0.067]$} & {$[0.051]$} & {$[0.134]$} \\
\hline \multirow[t]{2}{*}{ Interest rate differential with ECB Rate } & $0.211 * * *$ & $0.144 *$ & 0.076 & $0.498 * * *$ \\
\hline & {$[0.031]$} & {$[0.082]$} & {$[0.066]$} & {$[0.188]$} \\
\hline \multirow[t]{2}{*}{ Interest rate differential with Japan Rate } & $-0.130 * * *$ & -0.013 & $-0.179 * * *$ & $-0.371 * * *$ \\
\hline & {$[0.018]$} & {$[0.046]$} & {$[0.041]$} & {$[0.104]$} \\
\hline Constant & {$[0.054]$} & {$[0.164]$} & {$[0.116]$} & [0.908] \\
\hline Observations & 8,849 & 862 & 722 & 1,082 \\
\hline Fixed Effects & Yes & Yes & Yes & No \\
\hline Number of cn & 48 & 4 & 4 & 5 \\
\hline
\end{tabular}

TABLE IV: REGRESSION RESULTS II

Source: Author's Calculations

Here I investigate whether monetary policy spillovers, given by the coefficients of interest differentials with major advanced economies are significantly associated with the unexplained component of interest rates. A negative coefficient suggests that higher interest rate differentials, which contributes to decreasing the home interest rate. Meanwhile, a positive coefficient suggests that an increase in interest rate differentials contributes to increasing the home 
interest rate.

To examine differences in monetary policy spillovers, separate regressions were conducted for emerging markets in Asia, Latin America, and EU countries not adopting the Euro. Details of the countries in each regional grouping are given in the Appendix.

The results of the regression for all the data in the sample given in Table III (column 1) show that the interest rates from the monetary authorities in the three largest reserve currencies significantly affect interest rate decisions in other countries. These results are not surprising since these major advanced economies have deep financial and trade ties to EMEs. A closer look on different regions among EMEs, however, show that there are variations in the impact of interest rates in major advanced economies to them (See Table III, columns 2-4).

Table III shows that the associations between interest rates in Emerging Asia and Emerging Latin America and widening interest rate differential with the US are significant. Similarly, non-Euro Emerging EU Economies also tend to increase interest rates with increasing interest rate differential with the ECB. The results suggest that relative importance of the currency of the country adopting negative interest rates can explain why peripheral European countries are more responsive to the policy of the ECB because they are "pegged" to the Euro just as Emerging Asia and Emerging Latin America which were historically de-facto pegged to the US dollar [18], [19]. Furthermore, monetary policies in EMEs could also be influenced by the denomination of their international reserves in major reserve currencies like the US Dollar, Euro or the Japanese Yen.

In other cases, the negative sign of coefficients suggest that home countries tend to decrease interest rates with widening interest rate differential. The results suggest that monetary authorities in the home country are reducing interest rate given an increase in interest rate differential with a center country to soften speculative flows. In addition, it could also suggest that monetary policymakers are trying to accommodate to the weak external environment in major advanced economies by adopting looser monetary policy.

Despite differences in the significance of monetary spillovers from Japan and EU, the significance of the impact of US interest rates are consistent across EMEs. The results are in line with previous similar research like Hofmann and Tákats [8]. In addition, the findings are in accord with the significant financial and trade links of US to EMEs and that the US dollar is still the dominant reserve currency in the world.

To test for robustness of results, I used equation 2 and ran the regression for non-crisis episodes. Crisis episodes such as periods of currency crash and high inflation can lead to large swings in interest rates, which could affect the regression results. The findings provided in Table IV are generally in line with the results of the original regression. (See Appendix for details on the determination of currency crash and high inflation episodes.)

\section{CONCLUSION}

In this paper, I examined the heterogeneity of monetary policy spillovers to monetary responsiveness in emerging market economies. Using panel fixed effects regression, the results of this study show heterogeneity in the significance of policy spillover from US, ECB and Japan to emerging market economies. The results of this study show that international monetary policy spillovers influence the non-policy component of movements in interest rates, supporting the previous finding of Hofmann and Bogdanova [17]. Results provide policy implications on monetary policy independence in EMEs. As policymakers in Japan and EU implement a negative interest rate policy and as the US moves toward policy normalization, policymakers in emerging market economies may need to consider if they have enough room for monetary responsiveness as new developments arise.

\section{APPENDIX}

\begin{tabular}{|c|c|c|}
\hline Variable & Details & Source \\
\hline $\begin{array}{l}\text { short-term } \\
\text { interest } \\
\text { rate }\end{array}$ & Money Market Rates & IMF-IFS, quarterly data \\
\hline $\begin{array}{l}\text { output } \\
\text { growth }\end{array}$ & $\begin{array}{lr}\text { Log of } & \text { Industrial } \\
\text { Production } & \text { Indices } \\
\text { (supplemented } & \text { with } \\
\text { manufacturing } & \text { production } \\
\text { indices) } & \end{array}$ & IMF-IFS, quarterly data \\
\hline $\begin{array}{l}\text { potential } \\
\text { output } \\
\text { growth }\end{array}$ & $\begin{array}{l}\text { Log of HP filtered } \\
\text { production index with a } \\
\text { smoothing coefficient of } \\
1600\end{array}$ & $\begin{array}{l}\text { Author's calculations using } \\
\text { hprescott Stata ado file, } \\
\text { IMF-IFS, quarterly data [20] }\end{array}$ \\
\hline output gap & $\begin{array}{l}\text { output growth - potential } \\
\text { output growth }\end{array}$ & Author's calculations \\
\hline inflation & Annual growth of CPI & IMF-IFS, quarterly data \\
\hline $\begin{array}{l}\text { expected } \\
\text { inflation }\end{array}$ & $\begin{array}{l}5 \text { years average inflation } \\
\text { rate }[\mathrm{t}-5,5] \text { excluding } \\
\text { inflation episodes when } \\
\text { inflation } \geq 95 \% \text { percentile. }\end{array}$ & $\begin{array}{l}\text { Author's calculations, } \\
\text { IMF-IFS, quarterly data }\end{array}$ \\
\hline $\begin{array}{l}\text { high } \\
\text { inflation }\end{array}$ & Annual inflation $>20 \%$ & $\begin{array}{l}\text { Author's calculations, } \\
\text { IMF-IFS, quarterly data [21] }\end{array}$ \\
\hline $\begin{array}{l}\text { currency } \\
\text { crash }\end{array}$ & Annual depreciation $>15 \%$ & $\begin{array}{l}\text { Author's calculations, } \\
\text { IMF-IFS, quarterly data [21] }\end{array}$ \\
\hline
\end{tabular}

List of Countries in Table $1 \& 2$

\begin{tabular}{|c|c|}
\hline All & $\begin{array}{l}\text { Armenia, Bangladesh, Finland, Ireland, Jordan, Lithuania, } \\
\text { Pakistan, Slovenia, Spain, Tunisia, Ukraine, Japan, US }\end{array}$ \\
\hline Center & US, EU, Japan \\
\hline $\begin{array}{l}\text { Emerging } \\
\text { Asia }\end{array}$ & India, Malaysia, Philippines, Singapore \\
\hline $\begin{array}{l}\text { Emerging } \\
\text { Latin } \\
\text { America }\end{array}$ & Chile, Peru \\
\hline $\begin{array}{l}\text { Non Euro } \\
\text { Emerging }\end{array}$ & Romania \\
\hline
\end{tabular}

Notes: Calculated based on available data

\begin{tabular}{|c|c|}
\hline & List of Countries in Table 3 \\
\hline All & $\begin{array}{l}\text { Armenia, Austria, Bangladesh, Belgium, Bulgaria, Canada, } \\
\text { Chile, Colombia, Croatia, Cyprus, Czech Republic, } \\
\text { Denmark, El Salvador, Estonia, Finland, France, Germany, } \\
\text { Iceland, India, Indonesia, Ireland, Italy, Jordan, Rep. of } \\
\text { Korea, Latvia, Lithuania, Luxembourg, Malaysia, Mexico, } \\
\text { Netherlands, Norway, Pakistan, Peru, Philippines, Poland, } \\
\text { Portugal, Romania, Russia, Singapore, Slovak Republic, } \\
\text { Slovenia, Spain, Sweden, Tunisia, Ukraine, United } \\
\text { Kingdom, Uruguay }\end{array}$ \\
\hline $\begin{array}{l}\text { Emerging } \\
\text { Asia }\end{array}$ & India, Indonesia, Malaysia, Philippines \\
\hline $\begin{array}{l}\text { Emerging } \\
\text { Latin } \\
\text { America }\end{array}$ & Chile, Colombia, Mexico, Peru \\
\hline $\begin{array}{l}\text { Non Euro } \\
\text { Emerging }\end{array}$ & Bulgaria, Croatia, Czech Republic, Poland, Romania \\
\hline
\end{tabular}




\section{ACKNOWLEDGMENT}

The author thanks Ivy G. Sabuga of the Bangko Sentral ng Pilipinas for her valuable comments.

\section{REFERENCES}

[1] G. Kaminsky, C. Reinhart, and C. Végh, "When it rains, it pours: Procyclical capital flows and macroeconomic policies," NBER Macroeconomics Annual, vol. 19, pp. 11-53, 2004.

[2] B. Coulibaly, "Monetary policy in emerging market economies: What lessons from the global financial crisis?" International Finance Discussion Papers No. 1042, Washington: Board of Governors of the Federal Reserve System, 2012.

[3] E. E. Takáts and A. Vela, "International monetary policy transmission,” BIS Papers, vol. 78, pp. 25-44, August 2014.

[4] A. Belke and D. Gros, "Asymmetries in transatlantic monetary policy making: Does the ECB follow the fed?" Journal of Common Market Studies, vol. 43, pp. 921-946, 2005.

[5] M. Fratzcher, M. L. Duca, and R. Straub, "On the international spillovers of US quantitative easing," ECB Working Papers 1557, 2013.

[6] J. Chen, T. Mancini-Griffoli, and R. Sahay, "Spillovers from United States Monetary Policy on Emerging Markets: Different This Time?" IMF Working Paper 240, 2014.

[7] P. Tillman, "Unconventional monetary policy and the spillovers to emerging markets," Journal of International Money and Finance, vol. 66, pp. 136-156, 2016

[8] B. Hofmann and E. Tákats, "International monetary spillovers," BIS Quarterly Review, September 2015.

[9] J. Aizenman, M. Chinn, and H. Ito, "Monetary policy spillovers and the trilemma in the new normal: Periphery country sensitivity to core country conditions," NBER Working Paper No. 21128, 2015.

[10] A. K. Ozdagli and M. Weber. Monetary policy through production networks: Evidence from the stock market. [Online]. Available: https://ssrn.com/abstract $=2694330$

[11] Harding and Pagan, "Dissecting the cycle: A methodological investigation," Journal of Monetary Economics, vol. 49, no. 2, pp. 365-381, 2002

[12] B. Philippe, "SBBQ: Stata module to implement the Harding and Pagan (2002) business cycle dating algorithm," Statistical Software Components S457288, Boston College Department of Economics, Jan. 17, 2012.
[13] T. Didier, C. Hevia, and S. Schmukler, "How resilient and countercyclical were emerging economies during the global financial crisis?" Journal of International Money and Finance, vol. 31, no. 8, pp. 2052-2077, 2012.

[14] P. Disyatat, "Monetary policy implementation: Misconceptions and their consequences," BIS Working Papers No 269, 2008.

[15] J. Taylor, 1993, "Discretion versus policy rules in practice," Carnegie-Rochester Series on Public Policy, no. 39, pp. 195-214.

[16] M. Woodford, 2001, "The taylor rule and optimal monetary policy," American Economic Review, Papers and Proceedings, vol. 91, no. 2, pp. 232-237.

[17] B. Hofmann and B. Bogdanova, "Taylor rules and monetary policy: A global 'Great Deviation'?" BIS Quarterly Review, pp. 37-49, September 2012.

[18] J. Frankel and S. J. Wei, "Estimation of De Facto exchange rate regimes: synthesis of the techniques for inferring flexibility and basket weights," IMF Staff Papers, Palgrave Macmillan, vol. 55, no. 3, pp. 384-416, July 2008.

[19] R. McKinnon and G. Schnabl, "The East Asian Dollar Standard, fear of floating, and original sin," Review of Development Economics, vol. 8, no. 3, pp. 331-360, 2004

[20] C. Baum, "HPRESCOTT: Stata module to implement Hodrick-Prescott filter for timeseries data," Statistical Software Components S447001, Boston College Department of Economics, Oct. 28, 2009.

[21] C. Reinhart and K. Rogoff, 2009, This Time Is Different: Eight Centuries of Financial Folly, Princeton, NJ: Princeton University Press.

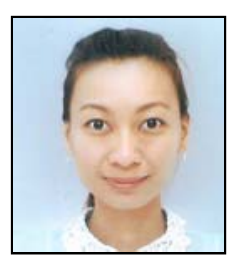

Jacinta Bernadette Rico Shirakawa is currently a research associate at Waseda University, Tokyo, Japan. Her research primarily focuses on international macroeconomics, particularly on monetary policy, recessions, and financial crises. She was involved in the study "The Role of ASEAN, the People's Republic of China, and India for a Balanced, Sustainable, and Resilient Asia" of Asian Development Bank Institute in 2010-2012.

She holds a PhD in international studies from the Graduate School of Asia Pacific Studies in Waseda University, Tokyo, Japan. She obtained an MA in Economics from the University of the Philippines and an MA in international relations from Waseda University. 